\title{
PENGARUH BELANJA MODAL DAN PENDAPATAN ASLI DAERAH TERHADAP INVESTASI SWASTA DI INDONESIA DENGAN PERTUMBUHAN EKONOMI SEBAGAI VARIABEL INTERVENING
}

\author{
THE EFFECT OF CAPITAL EXPENDITURE AND ORIGINAL LOCAL \\ GOVERNMENT REVENUE ON PRIVATE INVESTMENT IN INDONESIA WITH \\ ECONOMIC GROWTH AS INTERVENING VARIABLE
}

\author{
Prima Rosita Arini $S^{1}$, Manggar Wulan Kusuma ${ }^{2}$ \\ ${ }^{12}$ STIE YKPN Yogyakarta \\ ${ }^{1}$ sitarositaarini@gmail.com
}

\begin{abstract}
Abstrak
Pertumbuhan ekonomi merupakan masalah perekonomian suatu negara dalam jangka panjang, karena merupakan ukuran utama keberhasilan pembangunan dan hasilnya akan dapat dinikmati masyarakat sampai di lapisan paling bawah. Investasi swasta merupakan faktor penting untuk meningkatkan pertumbuhan ekonomi dan untuk meningkatkan investasi swasta diperlukan peran belanja modal dan Pendapatan Asli Daerah. Apabila nilai PAD suatu daerah meningkat maka dapat dikatakan bahwa tingkat kesejahteraan masyarakat di daerah tersebut juga tinggi. Jika tingkat kesejahteraan masyarakat suatu daerah tinggi maka kecenderungan yang ada adalah tingginya tingkat konsumsi masyarakat di daerah tersebut. Penelitian ini bertujuan untuk menguji apakah terdapat hubungan yang signifikan antara belanja modal, investasi swasta, $\mathrm{PAD}$, dan pertumbuhan ekonomi. Objek penelitian ini adalah seluruh provinsi yang ada di Indonesia kecuali Kalimantan Utara karena baru diresmikan menjadi provinsi di Indonesia pada tahun 2012. Penelitian ini menggunakan data keuangan daerah dan data investasi swasta di seluruh provinsi di Indonesia dari tahun 2010-2016. Teknik analisis data yang digunakan adalah analisis Partial Least Square (PLS). Hasil penelitian menunjukkan bahwa hubungan yang terjadi antara belanja modal dan investasi swasta adalah hubungan yang positif dan signifikan, hubungan yang terjadi antara PAD dan investasi swasta menunjukkan hubungan yang positif dan signifikan. Pengujian hubungan yang terjadi antara belanja modal dan pertumbuhan ekonomi memiliki hasil negatif dan tidak signifikan. Hubungan yang terjadi antara PAD dan pertumbuhan ekonomi adalah positif dan signifikan, dan begitu pula untuk hubungan antara pertumbuhan ekonomi dan investasi swasta.
\end{abstract}

Kata Kunci: belanja modal, pertumbuhan ekonomi, PAD, investasi swasta.

\begin{abstract}
Economic growth is an economic problem of a country in the long term because it is the main measurement of the success of development and the results will be enjoyed by the community at the lowest level. Private investment is an important factor to increase economic growth and to increase private investment, the role of capital expenditure and PAD is needed. If the value of PAD in an area increases, it can be said that the level of welfare of the people in those area is also high. If the level of community welfare in a region is high, then the level of consumption of the people in that area tends to increase. This study aims to examine whether there is a significant relationship between capital expenditure, private investment, PAD, and economic growth. The object of this research is all provinces in Indonesia except North Kalimantan because it was only officially opened as a province in Indonesia in 2012. This study uses regional financial data and private investment data in all provinces in Indonesia from 2010-2016. The data analysis technique used is Partial Least Square (PLS) analysis. The results show that capital expenditure and private investment have a positive and significant relationship, the relationship that occurs between PAD and private investment shows a positive and significant relationship. Tests of the relationship that occurs between capital expenditure and economic growth has a negative and insignificant result. The relationship between PAD and economic growth is positive and significant, and so is the relationship between economic growth and private investment.
\end{abstract}


Keywords: capital expenditure,economic growth, $P A D$, private investment

\section{PENDAHULUAN}

Investasi pemerintah daerah dalam Anggaran Pendapatan dan Belanja Daerah (APBD) tercermin melalui belanja modal yang dianggarkan setiap tahunnya. Apabila peningkatan penerimaan APBD kabupaten/kota di suatu provinsi ternyata tidak dikuti dengan peningkatan dana yang dialokasikan untuk investasi, hal tersebut akan berdampak terhadap penyediaan sarana fisik dan prasarana yang tidak memadai bagi daerah kabupaten dan kota yang mengalami pemekaran. Keterbatasan infrastruktur secara langsung akan menyebabkan potensi ekonomi suatu daerah tidak dapat didayagunakan secara optimal (Wahyuningsih, 2012). Menurut penelitian yang dilakukan oleh Hjerppe, et al (2007) dijelaskan bahwa investasi publik memiliki hubungan yang positif terhadap output sektor swasta. Berdasarkan hal tersebut terlihat bahwa diperlukan adanya peran pemerintah dalam rangka meningkatkan produksi sektor swasta yang nantinya akan berdampak pada pertumbuhan ekonomi.

Pertumbuhan ekonomi adalah proses perubahan kondisi perekonomian suatu negara secara berkesinambungan menuju keadaan yang lebih baik selama periode tertentu (Ernita, 2013). Pertumbuhan ekonomi yang berkesinambungan dapat meningkatkan kemakmuran masyarakat, sebab pertumbuhan ekonomi merupakan indikator untuk mengukur keberhasilan pembangunan dalam suatu negara. Pertumbuhan ekonomi merupakan masalah perekonomian suatu negara dalam jangka panjang, karena merupakan ukuran utama keberhasilan pembangunan dan hasilnya akan dapat dinikmati masyarakat sampai di lapisan paling bawah.

Untuk membiayai pembangunan daerah, salah satu modal yang digunakan bersumber dari pendapatan asli daerah (PAD). PAD yang merupakan salah satu sumber penerimaan daerah memiliki keterkaitan dengan pertumbuhan ekonomi. Menurut Saragih (2003), daerah yang memiliki pertumbuhan ekonomi positif memiliki kemungkinan kenaikan PAD atau dengan kata lain adanya peningkatan PAD merupakan akses dari pertumbuhan ekonomi atau PDRB dan diantara pertumbuhan ekonomi dan PAD diyakini terdapat adanya korelasi.

Investasi swasta merupakan faktor penting untuk meningkatkan pertumbuhan ekonomi, dan meningkatnya investasi swasta juga tak lepas dari meningkatnya pertumbuhan ekonomi di suatu negara. Pertumbuhan ekonomi tentunya memiliki pengaruh terhadap meningkatnya invetsasi swasta, karena apabila suatu daerah memiliki nilai pertumbuhan ekonomi yang tinggi maka daerah tersebut dianggap merupakan daerah yang menjanjikan untuk ditanamkan investasi, karena meningkatnya pertumbuhan ekonomi diiringi pula dengan meningkatnya kesejahteraan masyarakat. Penanaman Modal ini diawasi oleh Badan Koordinasi Penanaman Modal (BKPM). Dibentuknya lembaga pengawas BKPM adalah untuk mengatur kebijakan yang dapat meningkatkan minat investasi di Indonesia dan meningkatkan pelayanan, fasilitas, dan advokasi pelaksanaan penanaman modal. Melalui investasi swasta terjadi aliran modal yang berdampak kepada perubahan iklim bisnis, dan tentunya mengurangi hambatan kurangnya modal pembangunan yang terjadi di Indonesia. Dalam hal ini belanja modal memiliki peranan penting dalam meningkatkan produktivitas sektor swasta (Wang, 2005).

Tidak hanya belanja modal, Pendapatan Asli Daerah juga dapat merupakan menjadi salah satu faktor meningkatnya investasi swasta di Indonesia. Hal tersebut didasarkan pada logika apabila nilai PAD suatu daerah meningkat maka dapat dikatakan bahwa tingkat kesejahteraan masyarakat di daerah tersebut juga tinggi, tingginya kesejahteraan masyarakat tergambar melalui nilai IPM. Apabila tingkat kesejahteraan masyarakat suatu daerah tinggi maka kecenderungan yang ada adalah tingginya tingkat konsumsi masyarakat di daerah tersebut. Tingginya tingkat konsumsi yang ada akan membuat para investor apabila menanamkan investasinya disana maka akan memperoleh keuntungan yang tinggi pula.

\section{TUJUAN PENELITIAN}

Secara umum tujuan penelitian ini adalah untuk memberikan bukti empiris tentang hubungan yang terjadi antara belanja modal, PAD, pertumbuhan ekonomi dan investasi sektor swasta di Indonesia. Sedangkan secara spesifik, tujuan-tujuan yang ingin dicapai dalam penelitian adalah 
untuk mengetahui bagaimana belanja modal mempengaruhi investasi sektor swasta, bagaimana PAD mempengaruhi investasi sektor swasta, bagaimana belanja modal mempengaruhi pertumbuhan ekonomi, bagaimamana PAD mempengaruhi pertumbuhan ekonomi dan bagaimana pertumbuhan ekonomi mempengaruhi investasi sektor swasta.

\section{KAJIAN TEORI DAN PENGEMBANGAN HIPOTESIS Kajian Teori}

Menurut Ayu dan Arif (2007), belanja modal merupakan belanja yang memberikan manfaat lebih dari satu tahun untuk menambah aset atau kekayaan daerah, yang akan menimbulkan belanja lainnya. Belanja modal juga dimaksudkan untuk mendapatkan aset tetap pemerintah daerah, yakni peralatan, bangunan, infrastruktur, dan harta tetap lainnya (Abdullah dan Abdul,2006). Erlina dan Rasdianto (2013) berpendapat bahwa belanja modal merupakan pengeluaran anggaran untuk aset tetap berwujud yang memberi manfaat lebih dari satu periode akuntansi.

Penanaman modal merupakan langkah awal kegiatan pembangunan, investasi pada hakikatnya merupakan awal kegiatan pembangunan ekonomi. Dinamika penanaman modal mempengaruhi tinggi rendahnya pertumbuhan ekonomi. Investasi swasta memainkan peranan penting dalam membentuk pola pembangunan di daerah. Investasi ini akan menyebabkan terbentuknya modal daerah. Penanaman Modal Asing (PMA) dan Penanaman Modal Dalam Negeri (PMDN) menjadi salah satu sumber pembiayaan yang penting bagi wilayah yang sedang berkembang dan mampu memberikan kontribusi yang cukup besar bagi pembangunan. Ekspor dan investasi swasta memainkan peran penting dalam perekonomian suatu negara yang terbuka. Ekspor akan menghasilkan devisa, devisa akan digunakan untuk membiayai impor barang modal dan bahan baku yang diperlukan dalam proses produksi yang akan menciptakan nilai tambah bagi perekonomian. PDRB akan memberikan efek positif pada investasi swasta dan juga pengeluaran pemerintah memiliki pengaruh positif pada investasi swasta (Sutawijaya, et al., 2013).

Investasi pemerintah daerah dalam Anggaran Pendapatan dan Belanja Daerah (APBD) tercermin melalui belanja modal yang dianggarkan setiap tahunnya. Apabila peningkatan penerimaan APBD kabupaten kota di suatu provinsi ternyata tidak dikuti dengan peningkatan dana yang dialokasikan untuk investasi, hal tersebut akan berdampak terhadap penyediaan sarana fisik dan prasarana yang tidak memadai bagi daerah kabupaten dan kota yang mengalami pemekaran. Keterbatasan infrastruktur secara langsung akan menyebabkan potensi ekonomi suatu daerah tidak dapat didayagunakan secara optimal (Wahyuningsih, 2012).

Peningkatan PAD sebenarnya merupakan akses dari pertumbuhan ekonomi. Daerah yang pertumbuhan ekonomi positif mempunyai kemungkinan mendapatkan kenaikan PAD. Perspektif ini menyarankan bahwa seharusnya pemerintah daerah lebih berkosentrasi pada pemberdayaan kekuatan ekonomi lokal untuk menciptakan pertumbuhan ekonomi dari pada sekedar mengeluarkan produk perundangan terkait dengan pajak dan retribusi.

Todaro dan Stephen C.Smith (2006:9) berpendapat bahwa pertumbuhan ekonomi merupakan suatu ilmu yang mempelajari tentang peningkatan produksi barang dan jasa dalam kegiatan ekonomi masyarakat. Teori Pertumbuhan Ekonomi Simon Kuznets mendefinisikan pertumbuhan ekonomi sebagai peningkatan kemampuan suatu negara untuk bisa menyediakan barang-barang ekonomi bagi penduduknya (Djojohadikusumo, 1994:53). Dalam pelaksanaan pembangunan, pertumbuhan ekonomi yang tinggi adalah sasaran utama bagi negara-negara berkembang karena pertumbuhan ekonomi memiliki hubungan yang erat dengan peningkatan barang dan jasa yang diproduksi dalam masyarakat, sehingga semakin banyak barang dan jasa yang diproduksi maka kesejahteraan masyarakat akan meningkat (Badrudin, 2012).

\section{Pengembangan Hipotesis}

\section{Pengaruh Belanja Modal Terhadap Investasi Swasta}

Pada perekonomian Negara berkembang dilakukan penelitian terkait investasi publik dan investasi swasta yang dilakukan oleh Erden dan Holcombe (2005). Penelitian tersebut memberikan bukti bahwa belanja modal bersifat komplementer bagi investasi swasta. Sehingga meningkatnya investasi publik akan berdampak pada meningkatnya investasi swasta. Dalam penelitian tersebut juga dilakukan penelitian untuk Negara maju dengan model empiris yang sama dan diperoleh hasil 
bahwa faktor yang mempengaruhi investasi swasta di Negara maju berbeda dengan faktor yang mempengaruhi investasi swasta di Negara berkembang. Investasi publik memiliki dampak yang positif pada investasi swasta di Negara berkembang, namun tidak di Negara maju.

Berdasarkan complementary hypothesis pada Neoclassical arguments, belanja pemerintah pada infrasruktur akan meningkatkan produktivitas marjinal dari modal swasta dan kemudian akan mendorong investasi swasta yang lebih yang kemungkinan akan mengarah pada crowd-in effect atau meningkatnya investasi swasta meskipun beberapa kasus pada suatu negara mengarah pada crowd-out effect. Berdasarkan teori di atas, maka dapat dibentuk hipotesis:

\section{Hipotesis 1: Belanja Modal berpengaruh positif terhadap investasi swasta.}

\section{Pengaruh Pendapatan Asli Daerah Terhadap Investasi Swasta}

Pendapatan Asli Daerah adalah penerimaan yang diperoleh daerah dari sumber-sumber dalam wilayahnya sendiri yang dipungut berdasarkan peraturan daerah sesuai dengan peraturan perundang-undangan yang berlaku. Jika tingkat PAD suatu daerah meningkat maka dapat dikatakan bahwa tingkat kesejahteraan masyarakat di daerah tersebut meningkat. Semakin tinggi tingkat pendapatan suatu masyarakat maka sumber pendapatan asli daerah yang berasal dari pajak juga akan semakin tinggi. Tingginya pendapatan masyarakat dapat menjadi cerminan bahwa tingkat kesejahteraan masyarakat di daerah tersebut baik sehingga wilayah tersebut dapat dijadikan wilayah yang berprospek bagus untuk dijadikan lahan investasi oleh pihak swasta dalam negeri atau asing.

Apabila pendapatan naik, elastisitas permintaan yang diakibatkan oleh perubahan pendapatan (income elasticity of demand) adalah rendah untuk konsumsi bahan makanan. Sedangkan permintaan terhadap bahan-bahan pakaian, perumahan, dan barang-barang konsumsi hasil industri adalah sebaliknya. Sifat permintaan masyarakat tersebut sesuai dengan hukum Engels, teori Engels mengatakan bahwa, makin tinggi pendapatan masyarakat maka akan semakin sedikit proporsi pendapatan yang digunakan untuk membeli bahan pertanian, sebaliknya proporsi pendapatan yang digunakan untuk membeli produksi barang-barang industri menjadi bertambah besar. Berkembangnya dunia industri tidak dapat lepas dari peran investor yang akan melakukan investasi di Indonesia. Berdasarkan fenomena yang terjadi maka dapat dibentuk hipotesis:

\section{Hipotesis 2: PAD berpengaruh positif terhadap investasi swasta}

\section{Pengaruh Belanja Modal Terhadap Pertumbuhan Ekonomi}

Menurut Halim (2007) salah satu pengeluaran pemerintah adalah belanja modal yang memiliki pengertian pengeluaran anggaran untuk perolehan aset tetap dan aset lainnya yang memberi manfaat lebih dari satu periode akuntansi. Belanja modal termasuk: belanja tanah, belanja peralatan dan mesin, belanja modal gedung dan bangunan, belanja modal jalan, irigasi, dan jaringan, belanja aset tetap lainnya, dan belanja aset lainnya.

Pertumbuhan ekonomi yang terus menerus dapat dicapai oleh suatu daerah jika daerah tersebut selalu bisa memperbaiki infrastruktur yang ada di daerahnya. Belanja modal dimaksudkan untuk mendapatkan aset tetap pemerintah daerah, yakni peralatan, bangunan, infrastruktur, dan harta tetap lainnya. Dengan peningkatan pengeluaran belanja modal diharapkan dapat mendorong peningkatan ekonomi masyarakat yang pada gilirannya dapat memacu pertumbuhan pendapatan perkapita. Selain itu meningkatnya belanja modal juga diharapkan menjadi faktor pendorong timbulnya berbagai investasi baru di daerah dalam mengoptimalkan pemanfaatan berbagai sumber daya sehingga akhirnya dapat meningkatkan pertumbuhan ekonomi daerah.

Menurut Halim (2007), belanja modal merupakan belanja yang manfaatnya melebihi satu tahun anggaran dan akan menambah aset atau kekayaan daerah serta akan menimbulkan konsekuensi menambah belanja yang bersifat rutin seperti biaya pemeliharaan. Kesimpulan dari hasil penelitian yang dilakukan oleh Hakim (2013) dan Saragih (2003) menunjukkan bahwa sebenarnya belanja modal memiliki pengaruh yang positif terhadap pertumbuhan ekonomi. Berdasarkan hasil yang diperoleh dari penelitian-penelitian sebelumnya maka dapat dibentuk hipotesis sebagai berikut:

Hipotesis 3: Belanja modal berpengaruh positif terhadap pertumbuhan ekonomi. 


\section{Pengaruh Pendapatan Asli Daerah Terhadap Pertumbuhan Ekonomi}

Pertumbuhan ekonomi diukur dengan menggunakan PDRB Atas Dasar Harga Konstan. Tambunan (2006) menyatakan pertumbuhan PAD secara berkelanjutan akan menyebabkan peningkatan tingkat pertumbuhan Ekonomi sehingga dapat dikatakan bahwa PAD berpengaruh positif dengan pertumbuhan ekonomi di daerah. Harianto (2007) menjelaskan bahwa PAD merupakan salah satu sumber pembelanjaan daerah, jika PAD meningkat maka dana yang dimiliki oleh pemerintah daerah akan lebih tinggi dan tingkat kemandirian daerah akan meningkat pula, sehingga pemerintah daerah akan berinisiatif untuk lebih menggali potensi-potensi daerah dan meningkatkan pertumbuhan ekonomi. Pertumbuhan PAD secara berkelanjutan akan menyebabkan peningkatan pertumbuhan ekonomi daerah itu sendiri, (Tambunan, 2006). Dengan adanya penerimaan dari PAD dapat meningkatkan pertumbuhan ekonomi daerah dan akan berdampak terhadap pertumbuhan ekonomi nasional. Peningkatan PAD dapat meningkatkan investasi pemerintah daerah sehingga kualitas pelayanan publik semakin baik. Peningkatan PAD akan mendorong pertumbuhan ekonomi daerah. Adanya kenaikan PAD akan memicu dan memacu pertumbuhan ekonomi daerah menjadi lebih baik daripada pertumbuhan ekonomi daerah sebelumnya. Kenaikan PAD juga dapat mengoptimalkan dan meningkatkan aktivitas pada sektorsektor yang terkait dengan pertumbuhan ekonomi, seperti sektor industri dan perdagangan, sektorjasa, dan sektor-sektor lainnya. Berdasarkan penelitian-penelitian terdahulu maka dapat dibentuk hipotesis:

Hipotesis 4: Pendapatan Asli Daerah berpengaruh positif terhadap pertumbuhan ekonomi.

\section{Pengaruh Pertumbuhan Ekonomi Terhadap Investasi Swasta}

Pertumbuhan ekonomi adalah proses kenaikan kapasitas produksi suatu perekonomian yang diwujudkan dalam bentuk kenaikan pendapatan. Pertumbuhan ekonomi (Economic Growth) juga diartikan sebagai proses kenaikan output per kapita dalam jangka panjang. Sehingga dapat dikatakan bahwa pertumbuhan ekonomi bukan sesuatu yang instan.

Pertumbuhan ekonomi dinyatakan dengan kenaikan output (Produk Domestik Bruto) dan pendapatan riil perkapita merupakan salah satu ukuran kemakmuran suatu wilayah. Secara ringkas pertumbuhan ekonomi adalah peningkatan jumlah barang dan jasa yang diproduksi oleh suatu wilayah melalui kegiatan ekonomi selama kurun waktu tertentu. Hal ini diukur secara konvensional sebagai kenaikan Produk Domestik Bruto riil atau PDB riil yang dinyatakan dalam persen. Pertumbuhan biasanya dihitung secara riil, disesuaikan dengan laju inflasi.

Apabila suatu daerah memiliki tingkat pertumbuhan ekonomi yang tinggi maka hal tersebut memiliki arti bahwa penyediaan infrasruktur di daerah tersebut adalah baik. Sehingga wilayah tersebut dapat dikatakan layak untuk menjadi lahan investasi. PDRB per kapita merupakan salah satu cerminan dari daya beli masyarakat atau pasar. Makin tinggi daya beli masyarakat suatu negara atau daerah maka akan membuat negara atau daerah tersebut semakin menarik untuk menjadi lahan investasi baik yang dilakukan oleh orang Indonesia atau pun orang asing. Berdasarkan pemikiran dan fenomena yang terjadi maka dapat dibentuk hipotesis, yaitu:

Hipotesis 5: Pertumbuhan ekonomi berpengaruh positif terhadap investasi swasta.

Berbeda dengan penelitian-penelitian terdahulu, pada penelitian ini peneliti mencoba melihat bagaimana PAD sebagai cerminan tingkat konsumsi masyarakat mampu memberikan pengaruh terhadap investasi swasta, karena yang dilakukan penelitian sebelumnnya hanya melihat bagaimana investasi swasta mampu mempengaruhi PAD. Peneliti juga memasukkan variabel pertumbuhan ekonomi sebagai variabel intervening, karena meningkatnya PAD tentunya akan meningkatkan pertumbuhan ekonomi yang pada akhirnya nanti mampu membuat para investor tertarik untuk melakukan investasi di daerah tersebut. Daerah yang memiliki pertumbuhan ekonomi tinggi dianggap memiliki tingkat penyediaan infrastruktur dan kesejahteraan masyarakat yang tinggi, daerah yang seperti itu adalah daerah yang menarik untuk menjadi lahan investasi. 

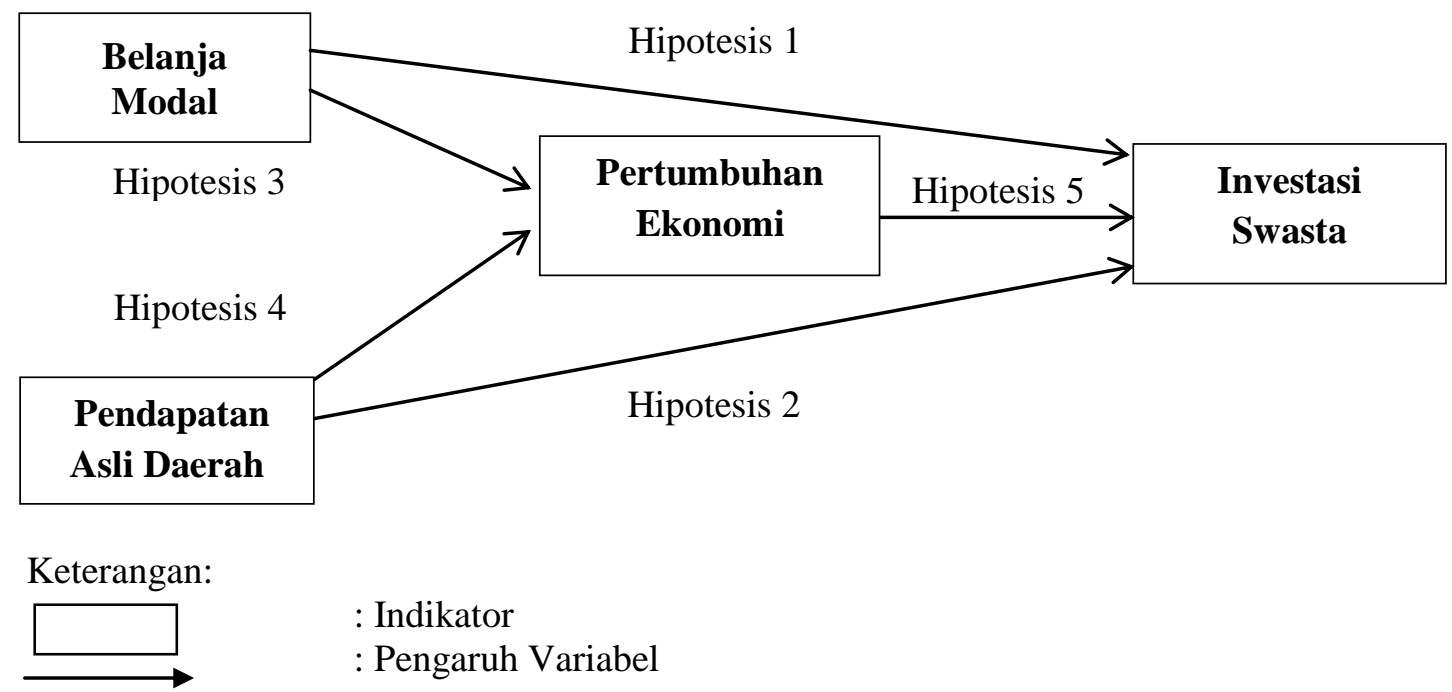

Gambar 1. Kerangka Pemikiran

\section{METODE}

\section{Sumber dan Data Penelitian}

Jenis data yang digunakan dalam penelitian ini adalah data sekunder. Data sekunder adalah data yang diolah dan diperoleh oleh peneliti dari pihak perusahaan maupun dari luar perusahaan yang berkaitan dengan permasalahan yang diteliti. Dalam penelitian ini, data diperoleh melalui studi kepustakaan dengan mempelajari sejumlah literatur, jurnal, paper, dan buku yang dinilai mampu memberikan kerangka teori bagi penelitian ini. Peneliti juga mempelajari informasi yang mendukung bagi penelitian ini yang tersedia di internet dan peraturan perundang-undangan mengenai pengelolaan keuangan negara dan kelembagaan institusi pemerintah. Hal ini dilakukan untuk memahami konteks permasalahan sehingga dapat melakukan analisis secara tajam dan mendalam. Data sekunder diperoleh dari Direktorat Jenderal Anggaran Departemen Keuangan berupa data Realisasi APBD dari tahun 2010 sampai dengan tahun 2016, data PDRB dari Badan Pusat Statistik, dan data investasi swasta dari BKPM.

\section{Variabel dan Definisi Operasional}

Klasifikasi variabel didasarkan atas kajian teoritis dan empiris sebagai acuan kerangka berfikir yang terdiri dari dua variabel.

Variabel eksogen adalah variabel yang mempengaruhi operasi dalam suatu model ekonomi dan variabel tersebut tidak dipengaruhi oleh setiap hubungan yang digambarkan oleh model tersebut. Variabel Eksogen dalam penelitian ini adalah Belanja Modal (X1) yang merupakan pengeluaran anggaran yang digunakan dalam rangka memperoleh atau menambah asset tetap dan asset lainnya yang memberi manfaat lebih dari satu periode akuntansi serta melebihi batasan minimal kapitalisasi aset tetap atau aset lainnya yang ditetapkan pemerintah dan Pendapatan Asli Daerah (X2) adalah pendapatan yang diperoleh daerah yang dipungut berdasarkan peraturan daerah sesuai dengan peraturan perundang-undangan. Arsyad (2004:17) berpendapat bahwa pertumbuhan ekonomi adalah perubahan Produk Domestik Regional Bruto (PDRB) per tahun yang dinyatakan dalam satuan persen.

Variabel endogen adalah variabel yang dipengaruhi oleh variabel eksogen. Variabel endogen dalam penelitian ini adalah Variabel endogen intervening yang merupakan variabel yang ikut berpengaruh ketika variabel eksogen mempengaruhi variabel endogen tergantung. Variabel endogen intervening dalam penelitian ini adalah Pertumbuhan Ekonomi (Y1) yang merupakan ilmu yang menggambarkan perkembangan suatu perekonomian dalam suatu tahun tertentu dibandingkan dengan tahun sebelumnya (Badrudin, 2012). Variabel endogen tergantung adalah variabel yang dipengaruhi oleh variabel eksogen maupun variabel endogen intervening. Variabel endogen 
tergantung dalam penelitian ini adalah Investasi Swasta (Y2) yang memiliki definisi Investasi sektor swasta adalah besarnya realisasi investasi/penanaman modal oleh masyarakat, baik berupa PMA maupun PMDN.

\section{HASIL DAN PEMBAHASAN Statistika Deskriptif}

Tabel 1. Hasil Uji Deskriptif

\begin{tabular}{cllll}
\hline & \multicolumn{1}{c}{ PAD } & \multicolumn{1}{c}{$\begin{array}{c}\text { BELANJA } \\
\text { MODAL }\end{array}$} & \multicolumn{1}{c}{ INVESTASI } & \multicolumn{1}{c}{ PDRB } \\
\hline Rata-Rata & \multicolumn{1}{c}{$3,260,458,191,239$} & $1,112,801,299,701$ & $7,839,196,278,785$ & $261,654,414,840,923$ \\
Maksimum & $39,322,613,624,142$ & $16,182,961,498,414$ & $95,851,268,047,020$ & $2,177,119,000,000,000$ \\
Minimum & $98,714,750,351$ & $108,997,026,000$ & $163,821,000$ & $5,389,831,565,710$ \\
\hline
\end{tabular}

Sumber: Data diolah (2018)

Dari data tersebut terlihat bahwa rata-rata PAD di seluruh provinsi di Indonesia adalah sebesar Rp3,260,458,191,239, rata-rata Belanja Modal adalah sebesar Rp1,112,801,299,701, ratarata Investasi adalah sebesar $\mathrm{Rp} 7,839,196,278,785$ dan rata-rata PDRB adalah sebesar Rp261,654,414,840,923.

Selain itu, hasil dari uji deksriptif terlihat bahwa nilai tertinggi untuk PAD dimiliki oleh provinsi DKI Jakarta tahun 2016 yaitu sebesar Rp39,322,613,624,142, untuk variabel Belanja Modal dimiliki oleh provinsi DKI Jakarta tahun 2016 yaitu sebesar Rp16,182,961,498,414, untuk variabel Investasi dimiliki oleh provinsi Jawa Barat tahun 2013 sebesar Rp95,851,268,047,020 dan variabel PDRB yang dimiliki oleh DKI Jakarta tahun 2013 sebesar Rp2,177,119,000,000,000.

Dari tabel tersebut terlihat pula nilai terendah yang dimiliki masing-masing variabel, untuk nilai terendah variabel PAD dimiliki oleh provinsi Maluku Utara tahun 2010 dengan nilai sebesar Rp98,714,750,351, untuk variabel Belanja Modal dimiliki oleh provinsi Gorontalo tahun 2010 sebesar Rp108,997,026,000, untuk variabel investasi dimiliki oleh provinsi Maluku tahun 2014 sebesar Rp163,821,000, sedangkan untuk variabel PDRB dimiliki oleh provinsi Maluku Utara tahun 2010 sebesar Rp5,389,831,565,710.

\section{Analisis Induktif Dengan Partial Least Square (PLS)}

Pada penelitian ini peneliti menggunakan alat statisik WarpPLS 6.0 untuk melakukan uji hipotesis. Analisis induktif dengan menggunakan Partial Least Square (PLS) meliputi penelitian goodness of fit model (inner model) yang berfungsi untuk mengetahui kecocokan suatu model yang digunakan dalam penelitian dengan menggunakan variabel PAD, belanja modal, investasi dan pertumbuhan ekonomi. Hasil pengujian goodness of fit model dapat dilihat pada Tabel 2 berikut ini:

Tabel 2. Nilai goodness of fit model

\begin{tabular}{ll}
\hline APC $=0,353, \mathrm{P}<0,001$ & Good if $\mathrm{P}<0,05$ \\
ARS $=0,749, \mathrm{P}<0,001$ & Good if $\mathrm{P}<0,05$ \\
AVIF $=4,333$ & Good if $\leq 5$
\end{tabular}

Sumber: Data diolah (2018)

Berdasarkan hasil pengujian model, nilai Average R-Squared (ARS) diperoleh hasil sebesar 0,749 dengan nilai $\mathrm{P}<0,001$. Berdasarkan hasil tersebut dapat disimpulan bahwa nilai ARS signifikan karena nilai $\mathrm{P}>0,05$, sedangkan nilai 0,749 menunjukkan bahwa variabel pada penelitian hanya mampu mempengaruhi variabel dependen sebesar 74,9\% dan sisanya sebesar $25,1 \%$ dipengaruhi oleh faktor lain diluar variabel dalam penelitian. Nilai Average Path Coefficient (APC) sebesar 0,353 dengan nilai $\mathrm{P}<0,001$, hal ini berarti nilai APC signifikan karena nilai $\mathrm{P}<0,05$. Karena nilai APC yang dihasilkan signifikan, maka dapat dibuktikan bahwa variabel endogen dan eksogen memiliki hubungan sebab dan akibat baik secara langsung maupun tidak langsung. Pada model penelitian ini tidak terjadi multikolinearitas, hal tersebut terbukti dari nilai Average Variance Inflation Factor (AVIF) sebesar 4,333 yang nilainya $\leq 5$. 


\section{Pengujian Hipotesis}

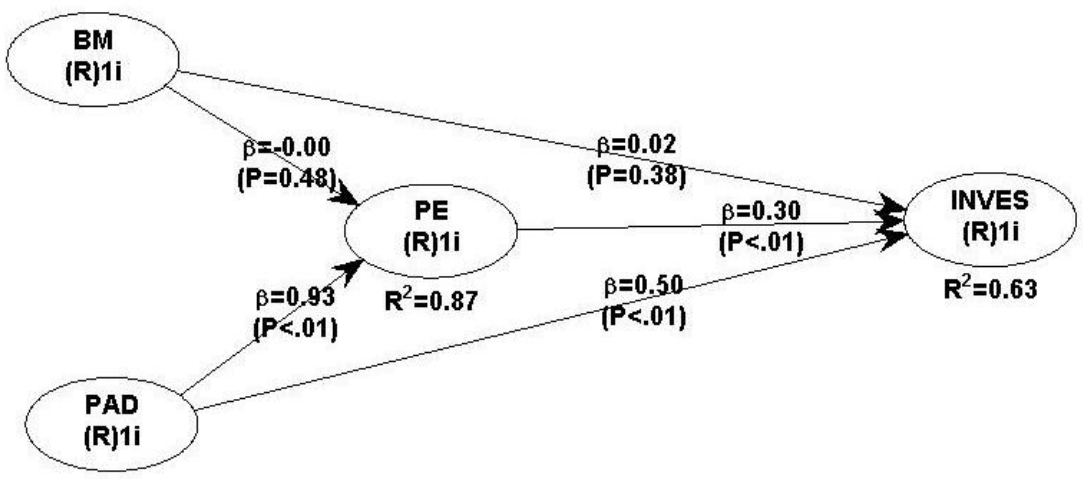

Gambar 2. Hasil Pengujian Hipotesis

Dari hasil pengujian hipotesis yang terlihat pada gambar 2 maka diperoleh hasil bahwa hubungan yang terjadi antara belanja modal dan investasi swasta adalah hubungan yang positif dan signifikan, hubungan yang terjadi antara PAD dan investasi swasta juga menunjukkan hubungan yang positif dan signifikan. Pengujian lain juga dilakukan untuk menguji hubungan yang terjadi antara belanja modal dan pertumbuhan ekonomi namun hasilnya adalah negatif dan tidak signifikan. Selain itu hubungan yang terjadi antara PAD dan pertumbuhan ekonomi adalah positif dan signifikan, dan hubungan yang muncul antara pertumbuhan ekonomi dan investasi swasta adalah positif dan signifikan.

\section{Belanja Modal memiliki hubungan yang positif terhadap Investasi Swasta}

Hal tersebut ditunjukkan dengan nilai koefisien sebesar 0,02. Tetapi karena $p$-value sebesar 0,38 yang lebih besar dari tingkat signifikansi sebesar 0,05 maka pengaruh yang muncul tidak signifikan. Pengaruh tidak signifikan ini muncul karena kurangnya sampel yang mewakili populasi yang ada. Berdasarkan pengujian hipotesis yang dilakukan oleh peneliti maka hipotesis yang menyatakan bahwa belanja modal berpengaruh terhadap investasi swasta dapat diterima.

Hasil penelitian ini sesuai dengan penelitian yang dilakukan oleh Wang (2005), pada penelitian Wang (2005) dibahas mengenai complementary hypothesis yang menjelaskan bahwa belanja pemerintah pada infrasruktur yang diukur dengan belanja modal kemungkinan akan meningkatkan produktivitas marjinal dari modal swasta dan kemudian akan mendorong investasi swasta yang lebih yang kemungkinan akan mengarah pada crowd-in effect atau meningkatnya investasi swasta sebagai akibat dari pengeluaran pemerintah dalam hal belanja modal.

\section{PAD memiliki hubungan yang positif terhadap Investasi Swasta}

Dari pengujian tersebut terlihat bahwa hubungan yang terjadi antara PAD terhadap investasi swasta adalah positif dan signifikan, hal tersebut terlihat dari nilai koefisien yang dihasilkan, yaitu sebesar 0,50 dengan $p$-value $<0,01$. Berdasarkan pengujian hipotesis yang dilakukan oleh peneliti maka hipotesis yang menyatakan bahwa Pendapatan Asli Daerah berpengaruh terhadap investasi swasta dapat diterima.

Hasil penelitian ini sesuai dengan pengembangan pengujian hipotesis mengenai apabila tingkat PAD suatu daerah meningkat maka dapat dikatakan bahwa tingkat kesejahteraan masyarakat di daerah tersebut meningkat. Semakin tinggi tingkat pendapatan suatu masyarakat maka sumber pendapatan asli daerah yang berasal dari pajak juga akan semakin tinggi. Tingginya pendapatan masyarakat dapat menjadi cerminan bahwa tingkat kesejahteraan masyarakat di daerah tersebut baik sehingga wilayah tersebut dapat dijadikan wilayah yang berprospek bagus untuk dijadikan lahan investasi oleh pihak swasta dalam negeri atau asing. Sehingga dapat dikatakan di Indonesia, meningkatnya PAD akan memberi dampak meningkatnya investasi swasta.

Belanja Modal berpengaruh negatif dan tidak signifikan terhadap pertumbuhan ekonomi 
Hal tersebut terlihat dari nilai koefisien jalur yang menunjukkan angka yang negatif yaitu sebesar $-0,003$ namun nilai $p$-value $=0,48$ yang diperoleh adalah sebesar yang lebih besar dari tingkat signifikansi yang telah ditentukan, dan angka p-value tersebut menunjukkan bahwa pengaruh yang diberikan adalah tidak signifikan. Berdasarkan pengujian hipotesis yang dilakukan maka dapat dikatakan bahwa hipotesis 3 yang menyatakan bahwa Belanja Modal berpengaruh terhadap Pertumbuhan Ekonomi tidak dapat diterima.

Pengaruh negatif dan tidak signifikan mungkin saja terjadi. Hal tersebut dikarenakan di Indonesia fenomena pertumbuhan ekonomi yang terjadi adalah pertumbuhan ekonomi eksklusif. Pertumbuhan ekonomi eksklusif dapat terjadi karena pembangunan yang dilakukan tidak berkualitas atau belum merata. Hasil yang diperoleh dalam penelitian ini sesuai dengan penelitian yang telah dilakukan oleh Sutawijaya (2013) yang menunjukkan bahwa pengeluaran pemerintah yang diukur menggunakan belanja modal memiliki pengaruh positif pada investasi swasta.

\section{Pendapatan Asli Daerah memiliki hubungan yang positif terhadap Pertumbuhan Ekonomi}

Hubungan tersebut terlihat dari nilai koefisien sebesar 0,93 dan tingkat $p$-value $<0,01$ yang nilainya lebih kecil dari tingkat signifikansi 0,05 yang nilainya lebih kecil dari tingkat signifikansi 0,05. Berdasarkan hasil pengujian tersebut makan hipotesis 4 yang menyatakan bahwa Pendapatan Asli Daerah berpengaruh terhadap pertumbuhan ekonomi diterima.

Hasil penelitian yang diperoleh menunjukkan hal yang sesuai dengan penelitian yang dilakukan oleh Rori et, al (2016) dan Saraswati dan Ramantha (2018), pada penelitian terdahulu terlihat bahwa PAD memberikan pengaruh yang positif terhadap pertumbuhan ekonomi karena pada dasarnya peningkatan PAD merupakan akses meningkatnya pertumbuhan ekonomi. Sehingga apabila terjadi peningkatan PAD akan diikuti dengan peningkatan pertumbuhan ekonomi.

\section{Pertumbuhan Ekonomi memiliki hubungan yang positif terhadap Investasi Swasta}

Hasil pengujian hipotesis menunjukkan bahwa hubungan antara pertumbuhan ekonomi terhadap investasi swasta adalah positif dan signifikan. Hal tersebut terlihat dari nilai koefisien sebesar 0,3 dan $p$-value sebesar 0,01 yang lebih kecil dari tingkat signifikansi 0,05. Berdasarkan hasil olah data yang telah dilakukan oleh peneliti, maka dapat disimpulkan bahwa hipotesis yang menyatakan bahwa Pertumbuhan Ekonomi berpengaruh terhadap Investasi Swasta dapat diterima.

Hasil penelitian ini sesuai dengan penelitian yang dilakukan oleh Sutawijaya (2013) yang menunjukkan bahwa PDRB akan memberikan efek positif pada investasi swasta. Jika suatu daerah memiliki tingkat pertumbuhan ekonomi yang tinggi maka hal tersebut memiliki arti bahwa penyediaan infrasruktur di daerah tersebut adalah baik. Sehingga wilayah tersebut dapat dikatakan layak untuk menjadi lahan investasi.

\section{KESIMPULAN \\ Kesimpulan}

Secara umum tujuan penelitian ini adalah untuk membuktikan hubungan yang terjadi antara belanja modal, PAD, pertumbuhan ekonomi dan investasi swasta. Berdasarkan hasil pembentukan hipotesis dan pengujian yang telah dilakukan oleh peneliti, maka dapat disimpulkan beberapa hasil dari penelitian ini.

Hasil dari penelitian ini terlihat hubungan yang terjadi antara belanja modal dan investasi swasta adalah hubungan yang positif dan signifikan, sehingga dapat dikatakan bahwa hipotesis 1 diterima. Hasil pengujian untuk hipotesis 2 menunjukkan hal yang serupa, dalam penelitian ini hipotesis 2 diterima karena hubungan yang terjadi antara PAD dan investasi swasta adalah positif dan signifikan. Pengujian lain juga dilakukan untuk hipotesis 3, hasil pengujian untuk hipotesis 3 menunjukkan hal yang sebaliknya, dalam penelitian ini hipotesis 3 tidak diterima karena hubungan yang terjadi antara belanja modal dan pertumbuhan adalah negatif dan tidak signifikan. Selain itu, pengujian yang dilakukan untuk menguji hipotesis 4 menunjukkan bukti bahwa hubungan yang terjadi antara PAD dan pertumbuhan ekonomi adalah positif dan signifikan, oleh karena itu hipotesis 4 dapat diterima. Hasil pengujian yang terakhir dilakukan untuk menguji hipotesis 5 , hasil dari pengujian hipotesis tersebut terlihat bahwa hubungan yang muncul antara Pertumbuhan 
Ekonomi dan Investasi Swasta adalah positif dan signifikan, maka hipotesis 5 dalam penelitian ini dapat diterima.

\section{Saran}

Saran bagi penelitian selanjutnya adalah peneliti dapat menambah variabel lain yang dapat mendukung pengembangan penelitian ini, sehingga hubungan dengan variabel lain dapat lebih terlihat. Selain itu bagi penelitian yang akan datang disarankan menggunakan data realisasi anggaran yang terbaru karena pada penelitian ini ketersediaan data merupakan kelemahan kami sehingga kami tidak bisa menggunakan data realisasi anggaran yang terkini yaitu tahun 2017 karena data tersebut belum tersedia.

\section{DAFTAR PUSTAKA}

Abdullah, Syukriy, Abdul Halim, 2006. "Studi Atas Belanja Modal pada Anggaran Pemerintah Daerah dalam Hubungannya dengan Belanja Pemeliharaan dan Sumber Pendapatan”, Jurnal Akuntansi Pemerintah Volume 2 Nomor 2.

Arsyad, Lincolin. 2010. Ekonomi Pembangunan. Edisi 5, Yogyakarta: UPP STIM YKPN.

Ayu, Diah, Kusumadewi dan Rahman, Arief, 2007, "Flypaper Effect Pada Dana Alokasi Umum (DAU) Dan Pendapatan Asli Daerah (PAD) Terhadap Belanja Daerah Pada Kabupaten/Kota Di Indonesia", JAAI, Vol. 11, No. 1, Juni.

Badrudin, Rudy. (2012). Ekonomika Otonomi Daerah. Yogyakarta: UPP STIM YKPN. Yogyakarta.

Djojohadikusumo, Sumitro. 1994. Perkembangan Pemikiran Ekonomi: Dasar Teori Ekonomi Pertumbuhan dan Ekonomi Pembangunan. Jakarta: LP3ES.

Erden Lutfi and Holcombe Randall G. 2005. The Effects of Public Investment On Private Investment In Developing Countries. Public Finance Review. 33: 575-602.

Erlina, Rasdianto, 2013, Akuntansi Keuangan Daerah Berbasis Akrual, Penerbit Brama Ardian

Ernita, Dewi, Syamsul Amar, dan Efrizal Syofyan. 2013. Analisis Pertumbuhan Ekonomi, Investasi, dan Konsumsi Di Indonesia. Jurnal Kajian Ekonomi. 1: 176-193.

Hakim, Abdul. 2013. Indeks Pembangunan Manusia di Indonesia. Jurnal Economica.

Halim, A. 2007. Akuntansi Sektor Publik Akuntansi keuangan daerah. Edisi Revisi. Salemba Empat. Jakarta

Harianto. 2007. Akuntansi Sektor Publik. Badan Penerbit Universitas Diponegoro. Semarang

Hjerppe, Reino, Pellervo Hamalainen, Jaakko Kiander, and Matti Viren. 2007. Do government expenditures increase private sector productivity? Cross-country evidence. International Journal of Social Economics. 34:345-360.

Peraturan Presiden Nomor 42 Tahun 2005 tentang Komite Percepatan Penyediaan Infrastruktur.

Rori, Chindy Febri, Antonius Y. Luntungan, Audie O Niode. 2016. Analysis Of The Influence of Local Own Revenue to Economic Growth In the Province of North Sulawesi In 2010-2013. Jurnal Berkala Ilmiah Efisiensi. 16 (02).

Saragih, Juli Panglima. 2003. Desentralisasi Fiskal dan Keuangan Daerah dalam Otonomi. Cetakan Pertama. Penerbit Ghalia Indonesia: Jakarta. 
Saraswati, Ida Ayu, I Wayan Ramantha. 2018. Pengaruh Pendapatan Asli Daerah Terhadap Pertrumbuhan Ekonomi Dengan Belanja Modal dan Investasi Swasta Sebagai Pemoderasi. E-Jurnal Akuntansi Universitas Udayana. 24(1)

Sutawijaya, Adrian and Zulfahmi. 2013. Faktor-Faktor yang Mempengaruhi Investasi Swasta di Indonesia. Trikonomika. 12: 32-39.

Tambunan, Tulus. 2006. Upaya-upaya Meningkatkan Daya Saing Daerah. Diakses dari http://www.kadin-indonesia.or.id.

Todaro, Michael P. and Stephen C. Smith. 2006. Economic Development. 9th Edition. New York: Pearson Addison Wesley.

Undang-Undang No. 33 Tahun 2004 Tentang Perimbangan Keuangan Antara Pemerintah Pusat dan Pemerintah Daerah.

Undang-Undang Nomor 25 Tahun 2007 tentang Penanaman Modal.

Undang-Undang Nomor 32 Tahun 2004 tentang Pemerintahan Daerah.

Wahyuningsih, Tri. 2012. Dampak Investasi Pemerintah dan Investasi Swasta Terhadap Pertumbuhan Ekonomi dan Kesejahteraan Masyarakat di Provinsi Maluku. Jurnal IQTISHODUNA. 8: 1-24.

Wang, Baotai. 2005. Effects of Government Expenditure on Private Investment: Canadian Empirical Evidence. Canada. Empirical Economics. 30: 493-504

[http://bkpm.go.id]. Diakses 24 Mei 2017

[http://bps.go.id]. Diakses 31 Mei 2017 